\title{
PROTEOLYTIC ACTIVITY, GROWTH AND NUTRIENT RELEASE BY BACILLUS CEREUS LW-17
}

\author{
Md Abdul Karim*, Nazneen Akhter and Sirajul Hoque ${ }^{1}$ \\ Department of Botany, University of Dhaka, Dhaka-1000, Bangladesh
}

Key words: Proteolytic acitivity, Bacillus cereus LW-17, Lake water, Nutrient release

\begin{abstract}
Bacillus cereus LW-17 enhanced net regeneration of dissolved inorganic nitrogen and phosphorus in the Gulshan lake water by about two-folds at temperatures of $26^{\circ} \mathrm{C}$ and $30^{\circ} \mathrm{C}$, respectively. Application of Bacillus cereus LW-17 would be promising for improvement of polluted environment.

Sampling site is a eutrophic area practicing bathing, swimming and washing clothes, utensils, etc. (Karim et al. 2012). Water samples were collected from surface water $(5 \mathrm{~cm}$ depth) with a 2.0 liter plastic bottle and were carried to the laboratory within an hour of sampling. Temperature of water samples was measured in situ with mercury thermometer, $\mathrm{pH}$ by a digital $\mathrm{pH}$ meter (Jenway 3310, U.K.). Dissolved oxygen (DO), conductivity and total dissolved oxygen (TDS) of water samples were measured by DO meter (Jenway $970 \mathrm{DO}_{2}$, Staffordshire, UK), conductivity meter (Hanna, MODEL-HI 9033) and TDS meter (Hanna, MODEL-HI 9034), respectively, while alkalinity was determined by titrimetric method.

A total of 85 fast growing bacterial colonies were isolated from surface water in September 2009. Out of them isolate LW-17 was selected for biotechnological application depending on growth pattern and proteolytic activities.

Bacterial re-suspension was prepared as described by Karim et al. 2003. Five ml of bacterial cell re-suspension was used as inoculum and it was inoculated into the treatment glass bottles (Schott, Duran, $250 \mathrm{ml}$, Germany). The glass bottles were incubated in a light condition (in duplicate) at $26^{\circ} \mathrm{C}$ temperature during September 2010 and at $30^{\circ} \mathrm{C}$ during October 2010 for 15 days without any shaking. Bacterial activities were evaluated measuring the changes of inorganic nutrient concentrations into the water during incubation with or without adding bacteria.

At five days interval two glass bottles were taken for chemical analysis. Water samples were passed through the filter paper (Whatman No. 42, England) to eliminate suspended solid particles. The concentrations of inorganic form of nitrogen (DIN: ammonium, nitrate and nitrite) and phosphorus (DIP) in the experimental glass bottles were measured. Water-soluble $\mathrm{NO}_{2}{ }^{-} \mathrm{N}$ was determined by modified Griess-Ilosvay (Barnes and Folkard 1951) method and water-soluble $\mathrm{NO}_{3}{ }^{-}$ -N was determined colorimetrically (Joergensen and Brookes 1990). Ammonium content of the samples was determined by Micro-Kjeldahl's method (Page et al. 1982). Soluble reactive phosphorus content of the water samples was determined by ascorbic acid blue color method (Murphy and Riley 1962).

Important physiological and biochemical characteristics were studied for identification of the selected isolate following Bergey's Manual of Systematic Bacteriology (Sneath et al. 1986).
\end{abstract}

*Author for correspondence: <makarim10@yahoo.com>. 'Department of Soil, Water and Environment, University of Dhaka, Dhaka-1000, Bangladesh. 
The physical and chemical properties of water samples were given in Table 1. In September water temperature was at $26^{\circ} \mathrm{C}$, while in October it was $30^{\circ} \mathrm{C}$. The result indicates a favourable temperature for bacterial growth. The $\mathrm{pH}$ of water sample was 6.98 in September and 7.38 in October. But, DO was $0.65(\mathrm{mg} / \mathrm{l})$ in September and $1.43(\mathrm{mg} / \mathrm{l})$ in October. The BOD was consisted with water temperature like $0.45(\mathrm{mg} / \mathrm{l})$ in September and $1.41(\mathrm{mg} / \mathrm{l})$ in October. The alkalinity, conductivity and TDS of water sample collected in September were 3.8 (meq/1), 1043 $(\mu \mathrm{S} / \mathrm{cm})$ and $210(\mathrm{mg} / \mathrm{l})$, respectively, while those were $4.1(\mathrm{meq} / \mathrm{l}), 1039(\mu \mathrm{S} / \mathrm{cm})$ and $193(\mathrm{mg} / \mathrm{l})$, respectively in October.

Table 1. Physical and chemical properties of the water sample collected on different sampling occasions.

\begin{tabular}{ccccccccc}
\hline $\begin{array}{c}\text { Date of } \\
\text { sampling } \\
(2010)\end{array}$ & $\begin{array}{c}\text { Air } \\
\text { temp. } \\
\left({ }^{\circ} \mathrm{C}\right)\end{array}$ & $\begin{array}{c}\text { Water } \\
\text { temp. } \\
\left({ }^{\circ} \mathrm{C}\right)\end{array}$ & $\mathrm{pH}$ & $\begin{array}{c}\mathrm{DO} \\
(\mathrm{mg} / \mathrm{l})\end{array}$ & $\begin{array}{c}\text { BOD } \\
(\mathrm{mg} / \mathrm{l})\end{array}$ & $\begin{array}{c}\text { Alkalinity } \\
(\mathrm{meq} / \mathrm{l})\end{array}$ & $\begin{array}{c}\text { Conductivity } \\
(\mu \mathrm{s} / \mathrm{cm})\end{array}$ & $\begin{array}{c}\text { TDS } \\
(\mathrm{mg} / \mathrm{l})\end{array}$ \\
\hline Sept. 26 & 25 & 26 & 6.98 & 0.65 & 0.45 & 3.8 & 1043 & 210 \\
Oct. 02 & 31 & 30 & 7.38 & 1.432 & 1.412 & 4.1 & 1039 & 193 \\
\hline
\end{tabular}

The isolate LW-17 exhibited remarkably high growth rates between $30^{\circ} \mathrm{C}$ and $40^{\circ} \mathrm{C}$ but didn't grow well at relatively low $\left(10^{\circ} \mathrm{C}\right)$ and high temperature $\left(50^{\circ} \mathrm{C}\right)$ (Fig. 1). In regards to proteolytic activities, LW-17 possessed high activities by clear zone into the medium and increased with incubation period at $37^{\circ} \mathrm{C}$ (Fig. 2). Considering growth pattern and proteolytic activities bacterial isolate LW-17 was selected for biotechnological application. For identification of the isolate LW17, morphological, physiological and biochemical characteristics were considered and provisionally identified as Bacillus cereus (Table 2).

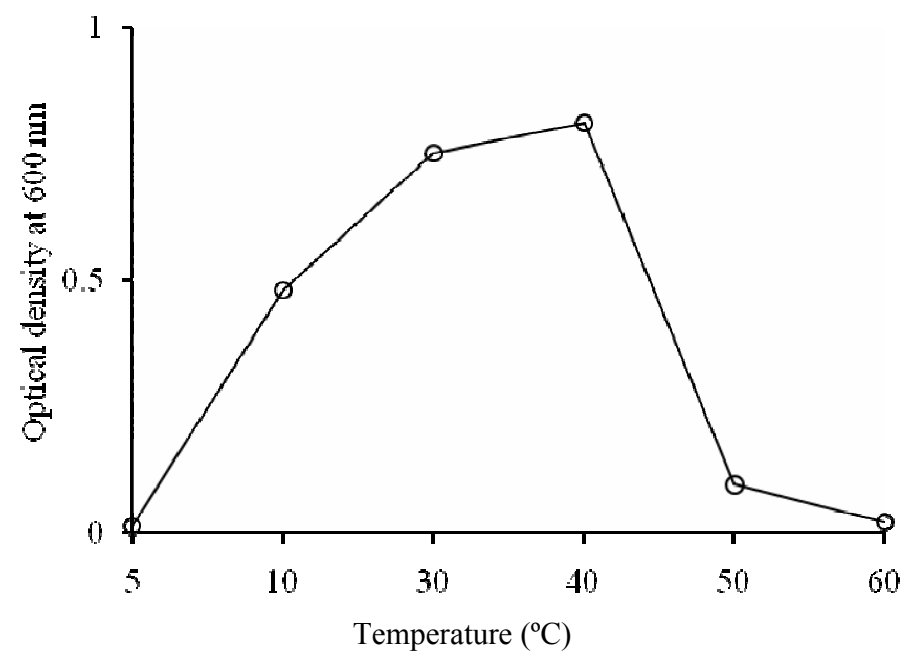

Fig. 1. Growth responses of Bacillus cereus LW-17 at different temperatures.

Higher release rate of DIN and DIP was obtained after the incubation of samples at $26^{\circ} \mathrm{C}$ and $30^{\circ} \mathrm{C}$ by adding $B$. cereus LW-17 (Fig. 3).

Inducing the growth of particular bacteria, biodegradation process of organic wastes could be stimulated even in large areas of water (Master and Mohn 1998). In the present study this method 
was tested in eutrophic lake water. The indigenous B. cereus LW-17 was isolated from the surface water of Gulshan lake which exhibited high growth rates and proteolytic activities at $30^{\circ} \mathrm{C}$ to $40^{\circ} \mathrm{C}$ (Figs 1,2). After adding B. cereus LW-17, net release rate of DIN and DIP were markedly enhanced in the samples collected both in September and October (Fig. 3).

Table 2. Characteristics of Bacillus cereus LW-17.

\begin{tabular}{lclc}
\hline Characteristics & Results & Characteristics & Results \\
\hline Gram reaction & + & KOH & + \\
Cell shape & $\begin{array}{c}\text { Short rod, occur in } \\
\text { chain and singly }\end{array}$ & Utilization of citrate & D \\
Spore & Ellipsoidal, central & Utilization of propionate & - \\
Catalase & + & Indole formation & - \\
Oxidase & - & Dihydroxy acetone production & - \\
VP & + & Fermentation & \\
MR & + & D-glucose (no gas) & + \\
Levan & - & L-arabinose & - \\
Phenayal alanine deaminase & - & D-xylose & - \\
Protease & + & D-mannitol & - \\
Motility & - & Degradation of tyrosine & + \\
Hydrolysis & & Nitrate reduction & + \\
$\quad$ Starch & + & Egg yolk lecithinase & + \\
\multicolumn{1}{c}{ Gasein } & + & Egg yolk lipase & + \\
\hline
\end{tabular}

$+=$ Positive,$-=$ Negative, $\mathrm{D}=$ Doubtful, $\mathrm{VP}=$ Voges-Proskauer and MR $=$ Methyl red.

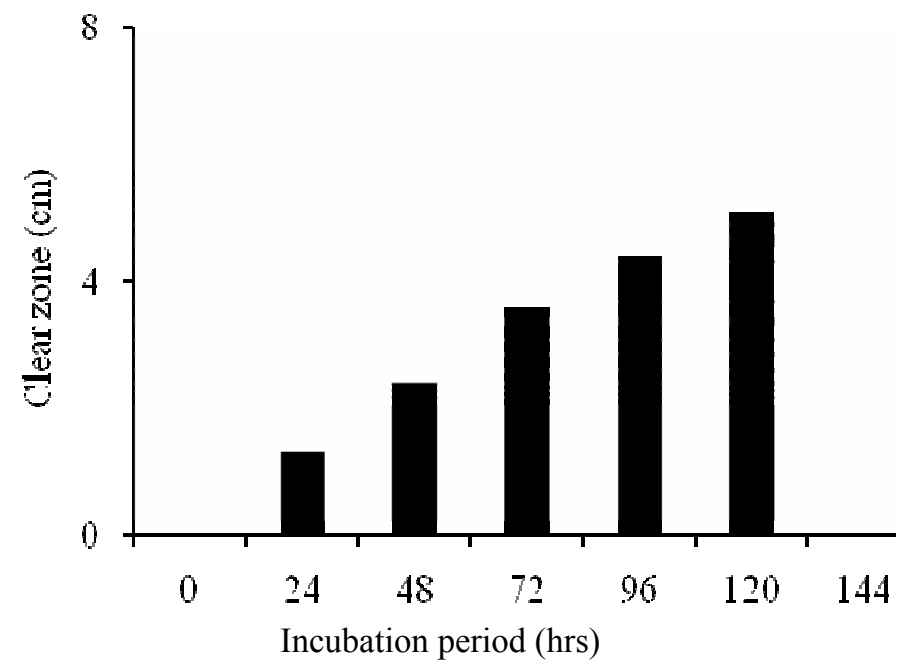

Fig. 2. Proteolytic activities of Bacillus cereus LW-17 at different incubation periods at $37^{\circ} \mathrm{C}$.

Patel et al. (2000) demonstrated that degradation of polymeric nitrogen compounds in the water column was limited by low dissolved oxygen or high inorganic nutrient concentrations in summer. Considering that the major pathway of utilization of organic nutrients by primary producers in nature is through bacterial or free enzymatic breakdown to easily exploitable inorganic components such as $\mathrm{NH}_{4}{ }^{+}$and DIP (Berman et al. 1991). 

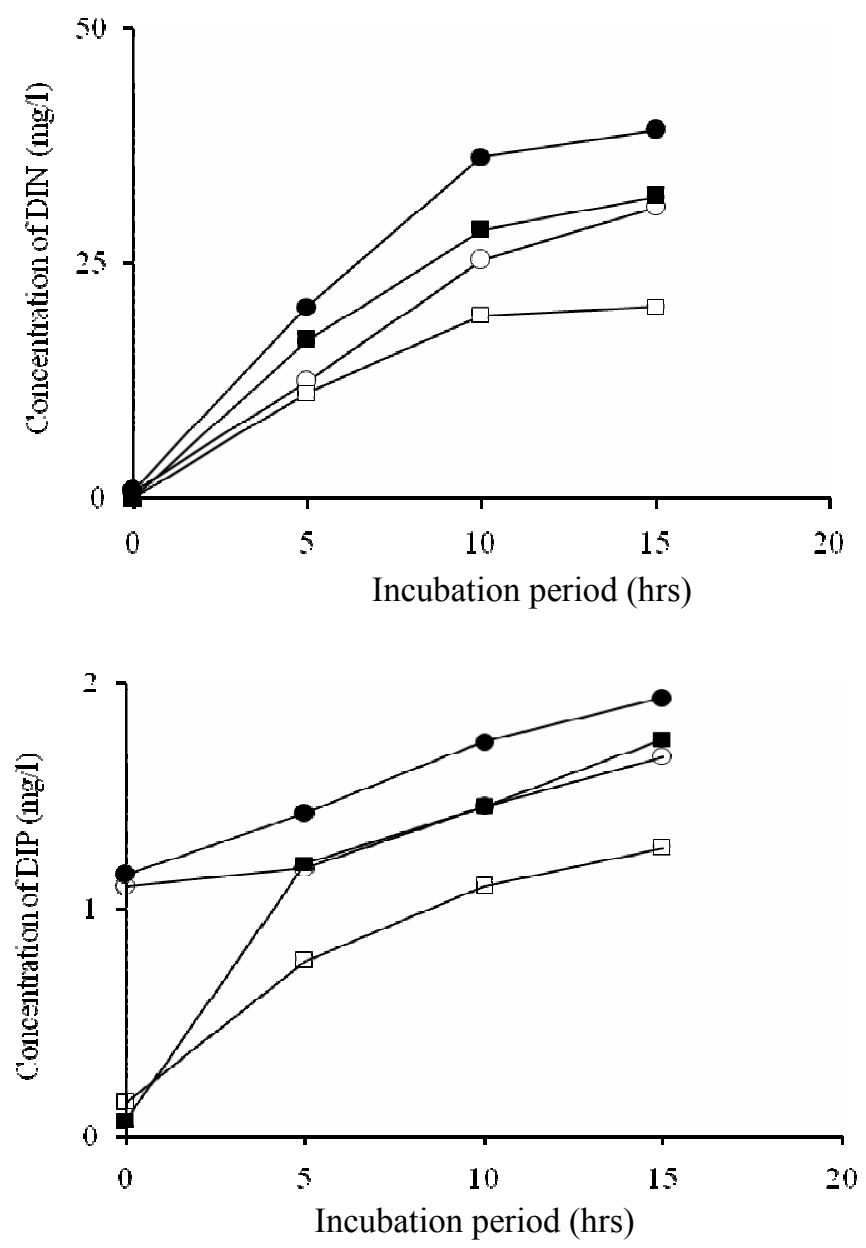

Fig. 3. Changes in concentration of dissolved inorganic nutrients by adding B. cereus LW-17. o and $\bullet=$ Incubation temperature at $26^{\circ} \mathrm{C}$ and sampling on September 26, 2010. $\square$ and $\mathbf{m}=$ Incubation temperature at $30^{\circ} \mathrm{C}$ and sampling on October 02,2010 . o and $\square=$ Without B. cereus LW-17 and $\bullet$ and $\mathbf{m}=$ With $B$. cereus LW-17.

In the present study, the role of B. cereus LW-17 was found promising in order to enhance release rate of DIN and DIP.

\section{References}

Barnes H and Folkard AR 1951. The determination of nitrites. Analyst (London). 76: 599-603.

Berman T, Bêchemin C and Maestrini SY 1999. Release of ammonium and urea from dissolved organic nitrogen in aquatic ecosystems. Aquat. Microb. Ecol. 16: 295-302.

Joergensen RG and Brookes 1990. Ninhydrin reactive nitrogen measurements of microbial biomass in $0.5 \mathrm{M}$ $\mathrm{K}_{2} \mathrm{SO}_{4}$ soil extracts. Soil Biol. and Biochem. 22: 1023-1027. 
Karim MA, Fukami K and Patel AB 2003. Enhancement of inorganic nutrient regeneration in a eutrophic sediment-bottom water complex system by adding effective indigenous bacteria. Fish. Sci. 69: 11441155.

Karim MA, Akhter N and Hoque S 2012. Bacterial status and pollution level in the water of Gushan lake, Dhaka. Bangladesh J. Zool. 40(1): 165-173.

Master ER and Mohn WW 1998. Psychrotolerant bacteria isolated from soil that degrade polychlorinated biphenyls at low temperature. Appl. Environ. Microbiol. 64: 4823-4829.

Murphy J and Riley JP 1962. A modified single solution method for determination of phosphate in natural water. Anal. Chem. Acta. 27: 31-36.

Page AL, Miller RH and Keeney DR 1982. Methods of soil analysis. Part 2. (2 ${ }^{\text {nd }}$ Ed). Madison, Wisconsin. p. 425.

Patel AB, Fukami K and Nishijima T 2000. Regulation of seasonal variability of aminopeptidase activities in surface and bottom waters of Uranouchi Inlet, Japan. Aquat. Microb. Ecol. 21: 139-149.

Sneath PHA, Mair NS, Sharpe ME and Holt JG (Eds) 1986. Bergey's manual of systematic bacteriology $\left(9^{\text {th }}\right.$ Ed). Vol. 2. The Williams and Wilkins Co., Baltimore, USA. pp. 965-1594.

(Manuscript received on 2 February, 2013; revised on 21 November, 2013) 